\title{
THE CHARACTERIZATION OF THE Ca-K GEOPOLYMER/SOLIDIFIED FLUID FLY-ASH INTERLAYER
}

\author{
"IVANA PERNÁ*, MONIKA ŠUPOVÁ*, TOMÁŠ HANZLÍČEK**** \\ *Institute of Rock Structure and Mechanics, Academy of Sciences of the Czech Republic, v.v.i., \\ Department of Materials Structure and Properties, 18209 Prague, Czech Republic \\ **Scientific and Engineering Park Buštěhrad, \\ U Panelárny 136, 27343 Buštěhrad, Czech Republic \\ "E-mail: perna@irsm.cas.cz
}

Submitted August 6, 2016; accepted October 12, 2016

\begin{abstract}
Keywords: Fluid fly ash, Blast-furnace slag, Geopolymer, Interlayer, Recycling
A Ca-K geopolymer matrix based on clay material and blast-furnace slag was filled with aggregates, ash pellets made from fluid fly ash, and the interlayer formed between the two components was studied. The scanning electron-microscopy investigation of the inseparable interlayer demonstrated that the pellets were not only enveloped in a geopolymer matrix but also incorporated through a thin, yet identifiable, surface pellet layer. The migration of calcium and potassium ions was detected and that changes in the quantity of these ions arise from their mobility. The interlayer on the edges of ash pellets was also studied by infrared analysis, which in this layer proved bands belonging to both participants, the matrix and the pellets. Based on the results, two different materials prepared from wastes could be used for the preparation of a new composite material and thus facilitate waste-material disposal.
\end{abstract}

\section{INTRODUCTION}

The amount of ash from coal-burning power plants rises significantly every day despite the fact that new effective technologies of coal combustion have been invented. Currently, produced ashes are typically dumped on landfills, and only a small part of these ashes is used [1-3], often on a laboratory scale only, e.g. for zeolite synthesis [4], construction materials [5-6], alumina extraction [7], glass-ceramic production [8], geopolymer matrix preparation [9-10] or as a road-base material [11].

The fluidized bed combustion (FBC) of coal minimizes air pollution caused by sulfur oxides which makes it environmentally friendly. A specific FBC temperature yields a combination of two main groups of ash components. One of them results from the addition of calcium carbonate into the burning layer, while the other is a residue of predominantly clayed materials. A fluid-burning temperature at $820^{\circ} \mathrm{C}$ decomposes the calcium carbonate, and the resulting calcium oxide captures almost all sulfur oxides from the coal and forms an anhydrite $\left(\mathrm{CaSO}_{4}\right)$. On the other hand, the crushedcoal particles burn in the fluid layer, and their effective burning is ensured by the revolve-ring system, where partially burned particles return to the fluid layer [11-12]. The clayed residue in coal is affected by the elevated temperature, and the revolve-ring burning system offers time for the rearrangement of the aluminum coordination to the oxygen in an alumina-silicate clayed lattice, which thereby produces changes in the lattice [13-15].

Previous works on the solidification of fluid coal ashes (C-ashes according to the ASTM classification) have demonstrated the formation of a solid, insoluble material when ash is treated (e.g. milled) and adequately watered [16-17]. Five-year experiments have verified their long-term stability even when they were submerged in water. The obtained slightly grayish cementing matter could be filled with various types of fillers (quartz sand, blast-furnace slag, etc.).

Understanding fluid-ash solidification was only the first step in the process of reusing these ashes. The second step was to find a way to use the solidified matter and take advantage of its durability, mechanical properties, and insolubility in water. The solidified fluid fly ash (FFA) was shaped into rounded oval pellets (12 $\mathrm{mm}$ in diameter), which were used as aggregates when surrounding the $\mathrm{Ca}-\mathrm{K}$ geopolymer matrix. The stability of the obtained material is closely connected to the formation of a stable coating interlayer between the two participants.

This article presents the characterization of the interlayer formed in a new composite material from a $\mathrm{Ca}-\mathrm{K}$ geopolymer matrix and pellets based on solidified fluid fly ash by scanning electron microscopy and infrared analysis. 


\section{MATERIALS AND METHODS}

\section{Materials \\ Ash pellets}

Previously obtained results based on experiments with the solidification of fluid coal ashes proved the formation of a solid and insoluble material with compressive strength between 13.0 and 15.0 $\mathrm{MPa}$ [16-17]. The knowledge of the stability of the material when submerged in water and the mechanical properties [16] were the main reasons for using this material as an aggregate in the form of pellets.

The ash pellets were prepared from fluid fly ash (Kladno Power Plant, Central Bohemian Region) in a mixture with bentonite. The best result was obtained with the combination of $10 \mathrm{wt}$. $\%$ of bentonite mixed into the fluid fly ash [16]. This clayed material comes from the northern part of Bohemia and is supplied by the company Keramost a.s., Most (Czech Republic). The main role of the natural milled bentonite is to fill the space between the round-shaped fly-ash particles. Moreover, it is well-known in ceramic practice that it also serves as a plasticizer when mixed with ash and water.
The chemical compositions of relevant materials are shown in Table 1, including loss-on-ignition (LOI) values. Table 2 presents the X-ray powder diffraction (XRD) results of the two raw materials needed for ashpellet preparation.

The results have shown that fresh fluid fly ash (FFA) has a major content of anhydrite, lime and quartz and a minority of calcite and hematite. Due to a reaction of FFA with air humidity, portlandite $\left(\mathrm{Ca}(\mathrm{OH})_{2}\right)$ could sometimes be detected instead of lime. Bentonite is formed by montmorillonite, quartz, anatase and calcite, with a minor amount of muscovite.

A commonly used pellet machine was applied for the preparation of ash pellets. The most important factors are the mixing time and an adequate proportion of water. The technology used requires 6.5 - 8 wt. \% of water. The pellets were stored under the cover of a plastic sheet to prevent fast water evaporation.

\section{A geopolymer matrix}

The geopolymer matrix (the $\mathrm{Ca}-\mathrm{K}$ geopolymer binder) was based on a mixture of an alkalized clayed material and blast-furnace slag in the ratio of 100:70,

Table 1. Chemical compositions of fluid fly ash (FFA) and bentonite (wt. \%).

\begin{tabular}{lcccccccccc}
\hline Oxides & $\mathrm{SiO}_{2}$ & $\mathrm{Al}_{2} \mathrm{O}_{3}$ & $\mathrm{Fe}_{2} \mathrm{O}_{3}$ & $\mathrm{CaO}$ & $\mathrm{TiO}_{2}$ & $\mathrm{MgO}$ & $\mathrm{K}_{2} \mathrm{O}$ & $\mathrm{Na}_{2} \mathrm{O}$ & $\mathrm{SO}_{3}$ & $\mathrm{LOI}$ \\
\hline FFA & 35.98 & 21.60 & 5.63 & 17.65 & 1.92 & 1.01 & 0.75 & 0.19 & 9.25 & 4.42 \\
Bentonite & 45.43 & 14.46 & 14.23 & 5.91 & 4.43 & 3.59 & 1.14 & 0.23 & - & 9.44 \\
\hline
\end{tabular}

Table 2. Mineralogical compositions of fluid fly ash (FFA) and bentonite.

\begin{tabular}{llll}
\hline Material & Major phases & Minor phases & Traces \\
\hline FFA & $\begin{array}{l}\text { anhydrite }\left(\mathrm{CaSO}_{4}\right), \\
\text { quartz }\left(\mathrm{SiO}_{2}\right), \\
\text { lime }(\mathrm{CaO})\end{array}$ & $\begin{array}{l}\text { calcite }\left(\mathrm{CaCO}_{3}\right), \\
\text { hematite }\left(\mathrm{Fe}_{2} \mathrm{O}_{3}\right)\end{array}$ & tricalcium aluminate $\left(\mathrm{Ca}_{3} \mathrm{Al}_{2} \mathrm{O}_{6}\right)$ \\
\hline Bentonite & $\begin{array}{l}\text { montmorillonite-18A } \\
\left(\mathrm{Na}_{0.3}\left(\mathrm{AlMg}_{2} \mathrm{Si}_{4} \mathrm{O}_{10}(\mathrm{OH})_{2} \cdot 6 \mathrm{H}_{2} \mathrm{O}\right),\right. \\
\text { calcite }\left(\mathrm{CaCO}_{3}\right),\end{array}$ & $\begin{array}{l}\text { muscovite }\left(\mathrm{KAl}_{2}\left(\mathrm{Si}_{3} \mathrm{Al}\right) \mathrm{O}_{10}(\mathrm{OH})_{2},\right. \\
\text { anatase }\left(\mathrm{TiO}_{2}\right)\end{array}$ & - \\
& quartz $\left(\mathrm{SiO}_{2}\right)$ & & \\
\hline
\end{tabular}

Table 3. Chemical compositions of geopolymer raw materials (wt. \%).

\begin{tabular}{lccccccrr}
\hline Material/Oxide & $\mathrm{SiO}_{2}$ & $\mathrm{Al}_{2} \mathrm{O}_{3}$ & $\mathrm{CaO}$ & $\mathrm{MgO}$ & $\mathrm{Fe}_{2} \mathrm{O}_{3}$ & $\mathrm{~K}_{2} \mathrm{O}$ & $\mathrm{SO}_{3}$ & $\mathrm{LOI}$ \\
\hline Mefisto & 50.28 & 41.99 & 0.14 & $<0.02$ & 1.03 & 0.59 & 0.21 & 3.65 \\
Blast-furnace slag & 22.38 & 8.09 & 37.44 & 3.51 & 2.31 & 1.26 & 7.46 & 14.70 \\
\hline
\end{tabular}

Table 4. Mineralogical compositions of geopolymer raw materials.

\begin{tabular}{llll}
\hline Material & Major phases & Minor phases & Traces \\
\hline Mefisto & quartz $\left(\mathrm{SiO}_{2}\right)$, & muscovite $\left(\mathrm{KAl}_{2}\left(\mathrm{Si}_{3} \mathrm{Al}\right) \mathrm{O}_{10}(\mathrm{OH})_{2}\right.$, & cristobalite $\left(\mathrm{SiO}_{2}\right)$, \\
& anatase $\left(\mathrm{TiO}_{2}\right)$ & hematite $\left(\mathrm{Fe}_{2} \mathrm{O}_{3}\right)$ & mullite $\left(\mathrm{Al}\left(\mathrm{A}_{1.83} \mathrm{Si}_{1.08} \mathrm{O}_{4.85}\right)\right)$ \\
\hline Blast-furnace slag & gehlenite $\left(\mathrm{Ca}_{2} \mathrm{Al}\left(\mathrm{Si}_{2} \mathrm{O}_{7}\right)\right)$, & wolastonite $\left(\mathrm{CaSiO}_{3}\right)$, & - \\
& calcite $\left(\mathrm{CaCO}_{3}\right)$, & merwinite $\left(\mathrm{Ca}_{3} \mathrm{Mg}_{\left.\left(\mathrm{SiO}_{4}\right)_{2}\right),}\right.$ & \\
& & bassanite $\left(\mathrm{CaSO}_{4} \cdot 0.5 \mathrm{H}_{2} \mathrm{O}\right)$, & \\
& & syngenite $\left(\mathrm{K}_{2} \mathrm{Ca}\left(\mathrm{SO}_{4}\right) \cdot 2 \mathrm{H}_{2} \mathrm{O}\right.$ & \\
\hline
\end{tabular}


studied and described earlier [18-20]. The geopolymer matrix components were: $\mathrm{K}_{2} \mathrm{O} / \mathrm{Al}_{2} \mathrm{O}_{3}=0.75 ; \mathrm{SiO}_{2} / \mathrm{Al}_{2} \mathrm{O}_{3}$ $=2.96 ; \mathrm{H}_{2} \mathrm{O} / \mathrm{K}_{2} \mathrm{O}=12.42$. The clayed material was Mefisto, an industrially prepared material with a metakaolin base (ČLUZ, Nové Strašecí, Czech Republic). The blast-furnace slag originated from a Kladno deposit (Central Bohemia); it was a by-product of cast-iron production in the $19^{\text {th }}$ and $20^{\text {th }}$ centuries. Tables 3 and 4 show their chemical and mineralogical compositions, respectively. The X-ray powder diffraction (XRD) of Mefisto has identified, in addition to several crystalline phases listed in Table 4, a large amount of an amorphous phase originating from the decomposition of kaolinite lattice during the industrial thermal activation of the clayed material. The dominant components in the blastfurnace slag (Table 4) are gehlenite $\left(\mathrm{Ca}_{2} \mathrm{Al}\left(\mathrm{Si}_{2} \mathrm{O}_{7}\right)\right)$ and calcite $\left(\mathrm{CaCO}_{3}\right)$ with minor participation of wolastonite merwinite, bassanite and syngenite.

\section{Sample preparation}

The dried ash pellets, used as pebbles, were placed into a plastic box and cemented together with a freshly prepared $\mathrm{Ca}-\mathrm{K}$ geopolymer binder (the clay material Mefisto was stirred with the alkaline solution for 10 min., after which the blast-furnace slag was added and mixed for another $10 \mathrm{~min}$ ). The geopolymer matrix was poured into these scattered pellets (a cross-section can be seen in Figure 1). The pellets, as aggregates, were submerged into the $\mathrm{Ca}-\mathrm{K}$ geopolymer matrix. The high viscosity of the matrix caused the formation of some enclosed air bubbles. On the left side, we could see slightly enveloped pellets, although they were firmly fixed to the sample surface.

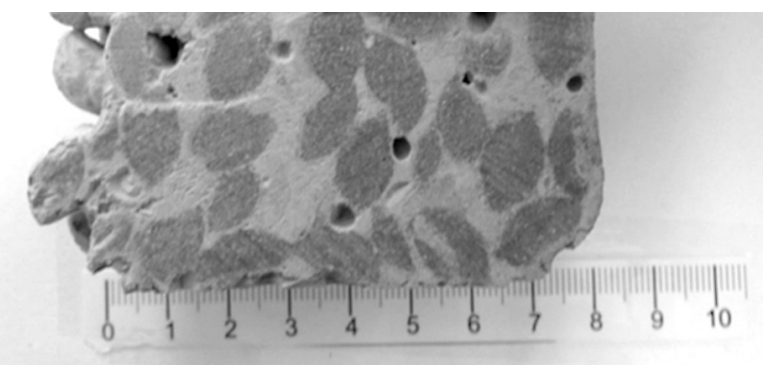

Figure 1. A cross-section of the $\mathrm{Ca}-\mathrm{K}$ geopolymer filled with FFA pellets.

\section{Methods}

Non-destructive X-ray fluorescence (XRF) spectrometry (Spectro IQ, Kleve, Germany) was used. The target material was palladium and the target angle from the central ray was $90^{\circ}$. The focal point was a $1 \mathrm{~mm}$ $\times 1 \mathrm{~mm}$ square, with a maximum anode dissipation of 50 watts and $10 \mathrm{cfm}$ forced-air cooling. The instrument was equipped with a HOPG Barkla crystal. The tested samples were prepared using the pressed-pellet method: $4.0 \mathrm{~g}$ of the material (a particle size of $15-20 \mu \mathrm{m}$ ) was mixed for 10 minutes with $0.9 \mathrm{~g}$ of a binding additive (HWC Hoechst wax, Germany). The pressing power was $80 \mathrm{kN}$. All of the results were automatically recalculated to the oxide forms.

The X-ray powder diffraction (XRD) data were collected at room temperature with an X'Pert PRO $\theta-\theta$ powder diffractometer with parafocusing BraggBrentano geometry using $\mathrm{CuK}_{\alpha}$ radiation $(\lambda=1.5418 \AA$, $\mathrm{U}=40 \mathrm{kV}, \mathrm{I}=30 \mathrm{~mA})$. The data were scanned with an ultrafast detector $\mathrm{X}^{\prime}$ Celerator over the angular range of $5-60^{\circ}(2 \theta)$ with a step size of $0.0167^{\circ}(2 \theta)$ and a counting time of $20.32 \mathrm{~s} \mathrm{step}^{-1}$. Data evaluation and identification of mineral phases were performed in the software package HighScore Plus.

The sample surface was studied using scanning electron microscopy (SEM) and energy dispersive spectroscopy (EDS) for an X-ray microanalysis. The sample was Au-coated with a K550X Emitech sputter coater in an atmosphere of argon and was examined with a Quanta 450 scanning electron microscope (EDAX Company, USA). The high vacuum mode was used, and images were taken with an ETD (EverhartThornley detector) in the secondary electron mode. Using the same microscope, an X-ray microanalysis (EDS analysis) of the chemical elements was conducted with an EDS silicon drift Si (Li) Apollo detector and an FET preamplifier. Data acquisition was performed using EDAX TSL OIM software with ZAF corrections.

The infrared (IR) spectra were measured using a Protégé 460 E.S.P. (Thermo Nicolet Instruments Co., Madison, USA) spectrometer over the range of $4000-400 \mathrm{~cm}^{-1}$ at a resolution of $4 \mathrm{~cm}^{-1}$, averaging 128 scans by the ATR technique to minimize disruption to the sample caused by the preparation techniques [21]. Spectral decomposition (or deconvolution) was performed using the OMNIC 7 program with a Gaussian function. The starting calculation parameters for the curve-fitting process, such as the number of component bands, band positions, width at half-maximum, relative intensities, and shape, were predetermined by the combined procedures of the secondary derivative method and Fourier self-deconvolution.

\section{RESULTS AND DISCUSSION}

\section{XRD results}

\section{A geopolymer matrix}

The combination of the clayed material and blastfurnace slag results in a geopolymer that can be referred to as a $\mathrm{Ca}-\mathrm{K}$ geopolymer matrix. XRD analysis of the resulting mixture confirms a roentgen-amorphous phase and the direct participation of the blast-furnace slag in the constitution of the final geopolymer matrix, as 
presented in Table 5. The content of gehlenite is reduced considerably, and new phases appear: arcanite $\left(\mathrm{K}_{2} \mathrm{SO}_{4}\right)$, calcite $\left(\mathrm{CaCO}_{3}\right)$, and andradite $\left(\mathrm{Ca}_{3} \mathrm{Fe}_{2}\left(\mathrm{SiO}_{4}\right)_{3}\right)$.

\section{Ash pellets}

The mineralogical composition of ash pellets, a material originating from fly ash (FFA) and bentonite, is a combination of roentgen-amorphous alumino-silicates and calcium carbonates (calcite/aragonite $\left(\mathrm{CaCO}_{3}\right)$ ), bassanite $\left(\mathrm{CaSO}_{4} \cdot 0.5 \mathrm{H}_{2} \mathrm{O}\right)$ and quartz $\left(\mathrm{SiO}_{2}\right)$ complemented with hematite $\left(\mathrm{Fe}_{2} \mathrm{O}_{3}\right)$ and other phases in trace amounts.

\section{SEM characterization}

SEM and EDS studies of the polished specimen from the sample show a heterogeneous calcareous substance in the previously described pellets [1617], in which the ash alumino-silicates form short- or longer-chained structures surrounded by a dominantly calcareous matter. Figure 2 depicts the coating material directly bonded to the pellets; its color changes are reflected in the various shades of the geopolymer binder at certain distances from the pellet surfaces.
The greater the distance from the pellet edges, the larger the change in the shade from whitish color to dark gray. The surrounding geopolymer binder changes its chemical composition and the observed fissures separate areas with different chemical compositions (Figures 2, 3). The EDS analyses presented in Table 6 show the chemical composition of the whole areas (surfaces A and C) along with selected points of strictly bordered areas on the pellet edges.

The geopolymer generally forms a homogenous amorphous matrix when the clayed geopolymer components are, in an ideal situation, dissolved in an aqueous alkali solution. In reality, the XRD study of the $\mathrm{Ca}-\mathrm{K}$ geopolymer presented in Table 5 shows well-defined crystal phases spread in a $\mathrm{Ca}-\mathrm{K}$ geopolymer matrix.

The polycrystalline character was specified and corroborated by the chemical composition of points E, F and G (Figure 3): The whitish areas are filled with the crystals, which are firmly encapsulated in the geopolymer. According to the X-ray diffraction (Table 5) the crystal phases contain sulfur oxides forming, with high probability, the arcanite.

The excess of potassium and the greater distance from the pellet edge lead to a decreased calcium content or its absence (points $F$ and $G$ ). The migration of

Table 5. Mineralogical compositions of the fresh ash pellets and $\mathrm{Ca}-\mathrm{K}$ geopolymer matrix.

\begin{tabular}{|c|c|c|c|}
\hline Material & Major phases & Minor phases & Traces \\
\hline Ash pellets & $\begin{array}{l}\text { calcite }\left(\mathrm{CaCO}_{3}\right) \\
\text { quartz }\left(\mathrm{SiO}_{2}\right) \\
\text { bassanite }\left(\mathrm{CaSO}_{4} \cdot 0.5 \mathrm{H}_{2} \mathrm{O}\right)\end{array}$ & hematite $\left(\mathrm{Fe}_{2} \mathrm{O}_{3}\right)$ & $\begin{array}{l}\text { gypsum }\left(\mathrm{CaSO}_{4} \cdot 2 \mathrm{H}_{2} \mathrm{O}\right) \\
\text { hydrophilite }\left(\mathrm{CaCl}_{2}\right) \text {, } \\
\text { phengite }\left(\left(\mathrm{K}_{0.9} \mathrm{Na}_{0.05}\right)\right. \\
\left.\left(\mathrm{Al}_{1.51} \mathrm{Mg}_{0.32} \mathrm{Fe}_{0.18} \mathrm{Ti}_{0.03}\right)\left(\mathrm{Si}_{3.4} \mathrm{Al}_{0.6} \mathrm{O}_{10}\right)(\mathrm{OH})_{2}\right)\end{array}$ \\
\hline $\begin{array}{l}\mathrm{Ca}-\mathrm{K} \\
\text { geopolymer } \\
\text { matrix }\end{array}$ & $\begin{array}{l}\text { quartz }\left(\mathrm{SiO}_{2}\right), \\
\text { calcite }\left(\mathrm{CaCO}_{3}\right)\end{array}$ & $\begin{array}{l}\text { gehlenite }\left(\mathrm{Ca}_{2} \mathrm{Al}\left(\mathrm{Si}_{2} \mathrm{O}_{7}\right)\right) \text {, } \\
\text { arcanite }\left(\mathrm{K}_{2} \mathrm{SO}_{4}\right)\end{array}$ & andradite $\left(\mathrm{Ca}_{3} \mathrm{Fe}_{2}\left(\mathrm{SiO}_{4}\right)_{3}\right)$ \\
\hline
\end{tabular}

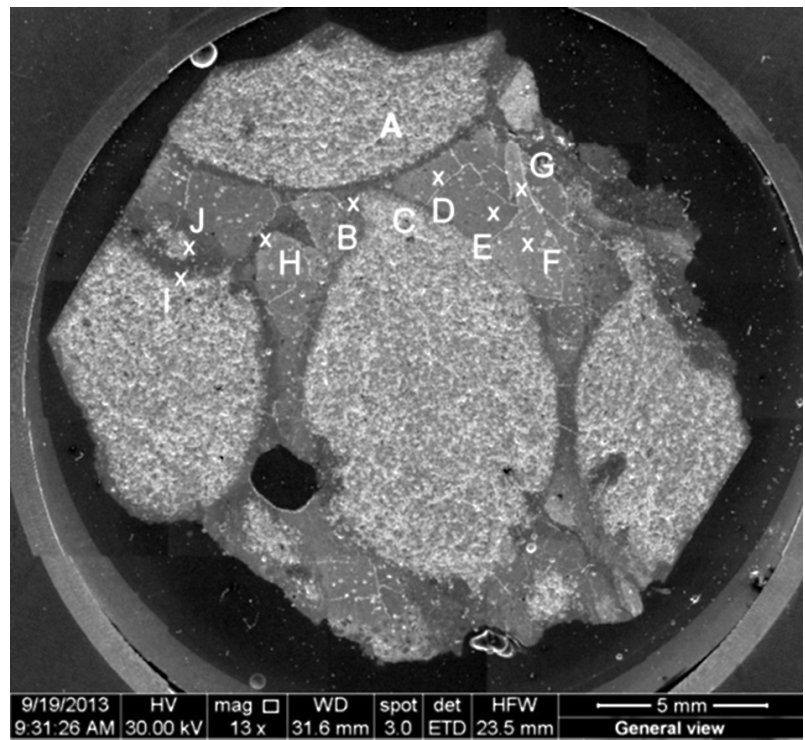

Figure 2. A general view of the pellets in the $\mathrm{Ca}-\mathrm{K}$ geopolymer surroundings (a polished specimen).

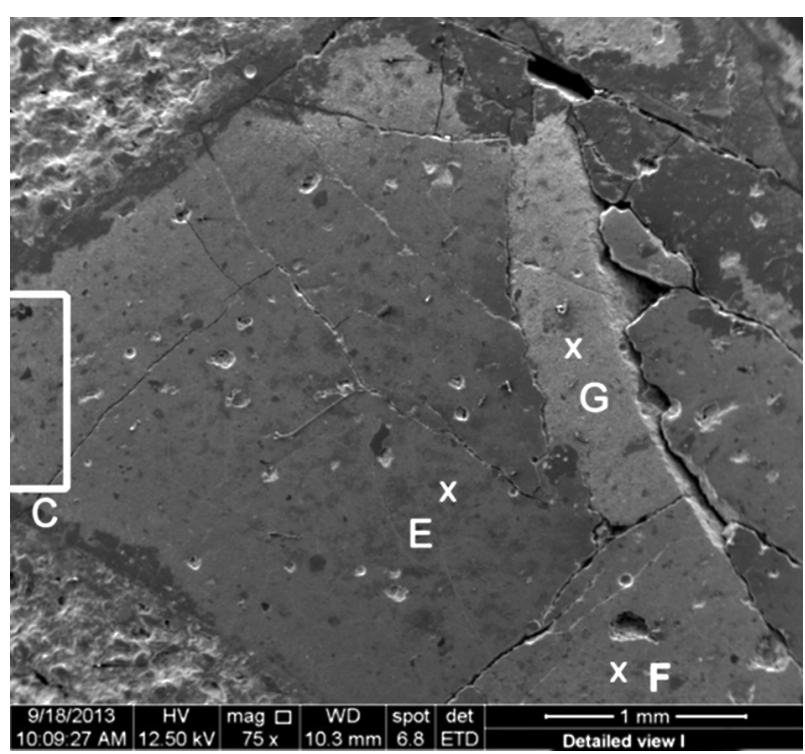

Figure 3. A detailed view of the geopolymer with color distinction (points $\mathrm{E}, \mathrm{F}$ and $\mathrm{G}$ ). 
potassium to a location farther from the pellet edge is associated with its increased mobility and potassiumsulfate crystallization. The lower calcium content is associated with its lower mobility as well as its fixation in previously formed crystal phases such as anhydrite

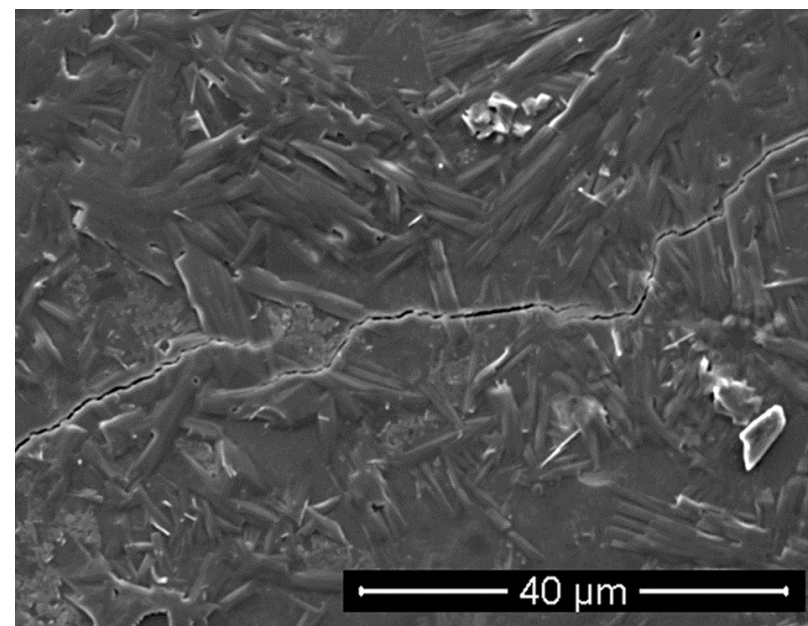

Figure 4. A detailed view of area C (2000× magnification) with crystals in the geopolymer surroundings.

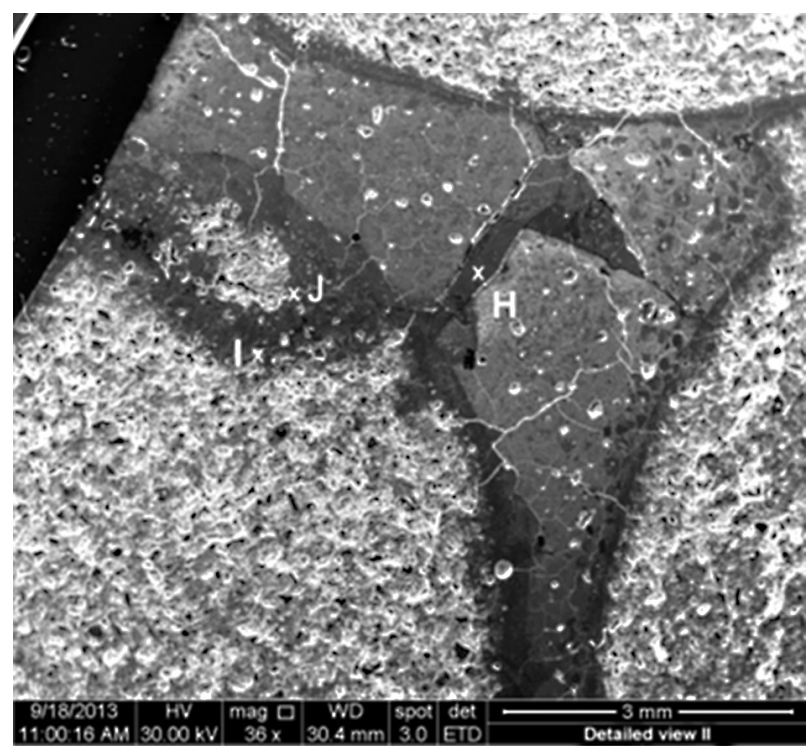

Figure 5. A detailed view of two points bordering the pellet (I and J) and an amorphous geopolymer (H).
$\left(\mathrm{CaSO}_{4}\right)$ and calcium carbonate $\left(\mathrm{CaCO}_{3}\right)$. The active forms of calcium present in the ashes such as calcium oxide and calcium hydroxide form primary ettringite ( $\left.6 \mathrm{Ca}(\mathrm{OH})_{2} \cdot \mathrm{Al}_{2}\left(\mathrm{SO}_{4}\right)_{3} \cdot 26 \mathrm{H}_{2} \mathrm{O}\right)$ in aqueous conditions. The area $\mathrm{C}$ could be perceived as a specific concentration of crystals (the whiter rods in the darker surroundings in Figure 4).

A specific case is noticeable in the small area (point I) placed between the small part of the chosen pellet and its remaining base (Figure 5). The piece of the pellet was most likely separated because of its higher porosity or lower strength on the pellet edge. Point I slightly differs from the chemical composition of the pellet in area A and contains i.e. titanium. Titanium oxide is present in coal ashes; together with iron oxides, these are components of clayed substance. A different situation could be seen in the case of point $\mathrm{J}$, where potassium and calcium are almost equal, but the content of sulfur is 10 times higher than in geopolymer surroundings (point $\mathrm{H}$ ). Even the brightness is similar to that of point $\mathrm{I}$; the edge point $\mathrm{J}$ represents a situation when the formation of sulfates is probable, detected also by the XRD and encapsulated in the geopolymer matrix. Figure 5 shows the position of point $\mathrm{H}$, which is the location between the two whitish areas. It looks like a "flow" of darkened material, which corresponds to the calculated geopolymer composition (the molar rate of $\mathrm{Al} / \mathrm{Si}=1: 2$ and $(\mathrm{K}+\mathrm{Ca}) / \mathrm{Al}=1.42)$.

\section{Infrared analyses}

Infrared spectroscopy was used to confirm the geopolymer bonds of the final solid bodies and to define the character of the original clayed material Mefisto, the slag and the final geopolymer matrix. The resulting curves in the determinative spectral regions are presented in Figure 6). The bands at $950-1250 \mathrm{~cm}^{-1}$ and $420-500 \mathrm{~cm}^{-1}$ are the most intense and they are assigned to an asymmetric stretching vibration of $\mathrm{Si}-\mathrm{O}-\mathrm{Si}$ and $\mathrm{Si}-\mathrm{O}-\mathrm{Al}$ and a bending vibration of the $\mathrm{Si}-\mathrm{O}$ groups. The band at $1079 \mathrm{~cm}^{-1}$, as well as the $797 \mathrm{~cm}^{-1}$ band of Mefisto, are associated with the asymmetric stretching of the $\mathrm{Si}-\mathrm{O}-\mathrm{T}$ group $(\mathrm{T}=\mathrm{Si}$ or $\mathrm{Al})$ in metakaolinite,

Table 6. Chemical compositions detected by EDS (wt. \%).

\begin{tabular}{lccccccccccc}
\hline Element & $\mathrm{C}$ & $\mathrm{O}$ & $\mathrm{Na}$ & $\mathrm{Mg}$ & $\mathrm{Al}$ & $\mathrm{Si}$ & $\mathrm{S}$ & $\mathrm{K}$ & $\mathrm{Ca}$ & $\mathrm{Ti}$ & $\mathrm{Fe}$ \\
\hline Surface A & 7.30 & 33.45 & 0.2 & 1.07 & 22.01 & 16.91 & 2.22 & 3.04 & 7.81 & 1.24 & 4.75 \\
Point B & 3.88 & 32.82 & 0.47 & 0.42 & 17.17 & 28.32 & 1.02 & 11.98 & 2.11 & 1.09 & 0.73 \\
Surface C & 5.04 & 31.35 & 0.28 & 0.54 & 10.69 & 17.96 & 9.38 & 16.95 & 7.82 & - & - \\
Point D & 5.67 & 24.70 & 0.18 & - & 4.48 & 7.34 & 15.84 & 39.13 & 0.67 & - & - \\
Point E & 5.08 & 30.96 & 0.41 & 0.49 & 11.95 & 20.49 & 6.64 & 22.77 & 1.20 & - & - \\
Point F & 5.93 & 27.26 & 0.27 & - & 6.42 & 10.79 & 13.65 & 35.67 & - & - & - \\
Point G & 4.95 & 25.62 & 0.14 & - & 3.76 & 2.25 & 18.56 & 44.73 & - & - & - \\
Point H & 13.27 & 29.8 & 0.36 & 0.70 & 14.42 & 26.75 & 0.34 & 11.14 & 3.21 & - & - \\
Point I & 21.49 & 29.97 & 0.16 & 2.04 & 12.69 & 17.83 & 1.70 & 1.31 & 8.74 & 0.91 & 3.15 \\
Point J & 8.26 & 31.95 & 0,27 & 0.60 & 8.59 & 12.03 & 11.04 & 12.91 & 12.44 & - & 1.89 \\
\hline
\end{tabular}


where $\mathrm{Si}$ or $\mathrm{Al}$ is tetra-coordinated. However, the band at $1079 \mathrm{~cm}^{-1}$ can also be related to quartz. The band at $469 \mathrm{~cm}^{-1}$ is related to the $\mathrm{Si}-\mathrm{O}$ bending vibration. The band at $912 \mathrm{~cm}^{-1}$ belongs to six-coordinated $\mathrm{Al}-\mathrm{O}$, but, in our case, it is hidden in the wide band at $797 \mathrm{~cm}^{-1}$, which can also contain another band related to quartz $\left(778 \mathrm{~cm}^{-1}\right)$. It can be stated that Mefisto contains a large amount of $\mathrm{Al}(\mathrm{IV})$ and a lower amount of $\mathrm{Al}(\mathrm{VI})$. As arises from Figure 6, the position of the principal $\mathrm{Si}-\mathrm{O}-\mathrm{T}$ asymmetric stretching band located originally at $1079 \mathrm{~cm}^{-1}$ in the Mefisto sample has shifted to lower wavenumbers $\left(1014 \mathrm{~cm}^{-1}\right)$ through a reaction with blast-furnace slag. This shift indicates an increase in the substitution of the tetrahedral $\mathrm{Al}$ in the silicate network due to alkaline activation and the consequently developing geopolymer network [22]. This effect can further be confirmed by the reduction in the intensity of the spectral shoulder at $\sim 560 \mathrm{~cm}^{-1}$, attributable to silicates and/or aluminosilicates with long-range

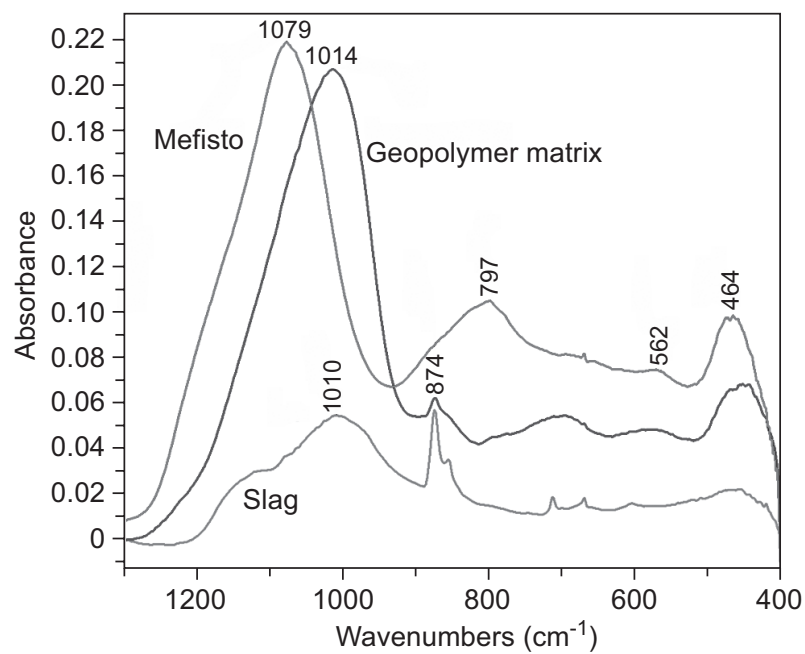

Figure 6. Infrared analysis of the slag, clayed material Mefisto and the $\mathrm{Ca}-\mathrm{K}$ geopolymer matrix. structural order in the geopolymer matrix [23]. The slag and the sample of the $\mathrm{Ca}-\mathrm{K}$ geopolymer matrix contain also carbonates $\left(875 \mathrm{~cm}^{-1}\right)$.

The deconvoluted spectrum of the $\mathrm{Ca}-\mathrm{K}$ geopolymer matrix presented in Figure 7 reveals the bands belonging to metakaolinite at $1077 \mathrm{~cm}^{-1}$ and the weak band at $1215 \mathrm{~cm}^{-1}$ as the spectral shoulders of the principal band at $1070 \mathrm{~cm}^{-1}$. The other bands belong to $\mathrm{Si}-\mathrm{O}$ and $\mathrm{Si}-\mathrm{O}-\mathrm{Al}$ at 1135 and $978 \mathrm{~cm}^{-1}$, respectively. As a consequence of polycondensation with alternating $\mathrm{Si}-\mathrm{O}$ and $\mathrm{Al}-\mathrm{O}$ bonds, the original band at 1070 $\mathrm{cm}^{-1}$ has shifted to lower wavenumbers and the new band at $1020 \mathrm{~cm}^{-1}$ for $\mathrm{Si}-\mathrm{O}-\mathrm{Al}$ asymmetric stretching has been formed [24].

The deconvoluted spectrum of pellets shown in Figure 8 reveals the bands belonging to $\mathrm{Si}-\mathrm{O}-\mathrm{Al}$ chaining at $1040 \mathrm{~cm}^{-1}[21-22,25]$. The band at $1114 \mathrm{~cm}^{-1}$ can be attributed to sulfates which are present in fluid fly ash and which are related to crystal phases found using the XRD method (Table 5). In this spectrum, one can also see the bands at 986 and $1174 \mathrm{~cm}^{-1}$, which are probably attributable to $\mathrm{Si}-\mathrm{O}$ vibrations of the other silicates present in the samples as impurities.

The deconvoluted spectrum of the layer formed between the pellets and the $\mathrm{Ca}-\mathrm{K}$ geopolymer matrix is presented in Figure 9. The spectrum clearly contains bands belonging to both materials, ash pellets (the bands at $\sim 1165$ and $1111 \mathrm{~cm}^{-1}$ ) and the geopolymer matrix (the bands at $\sim 1065,1023$ and $979 \mathrm{~cm}^{-1}$ ). This layer forms "interspace" connecting both materials and supports the results obtained by SEM and EDS analyses.

The applied XRD analysis has shown that both matters used (the matrix and the pellets) contain roentgen-amorphous alumino-silicates and calciumbased crystal compounds in their structures. The incorporation of the pellets made from fluid fly ash into the $\mathrm{Ca}-\mathrm{K}$ geopolymer matrix and the detection of the interlayer on the edges of the pellets prove the

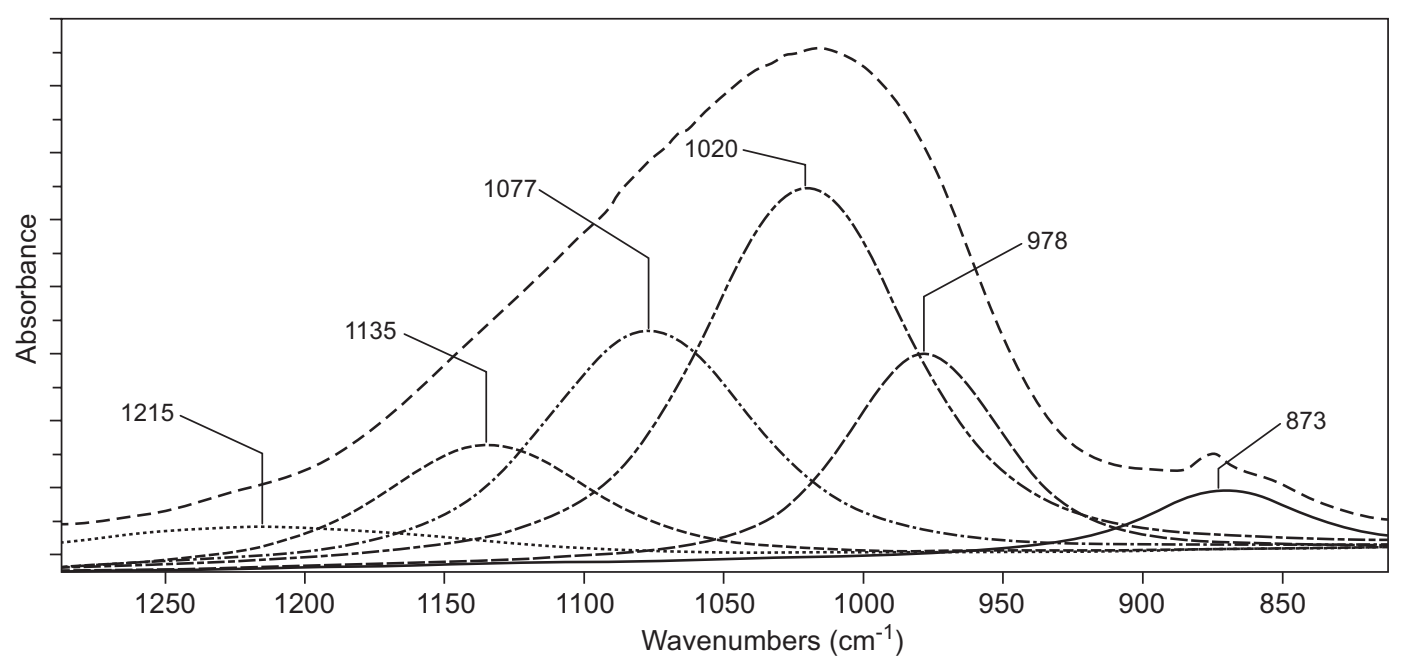

Figure 7. Deconvolution of the complex bands of the $\mathrm{Ca}-\mathrm{K}$ geopolymer matrix. 
interaction between the calcium-containing matter (the pellets - surface A) and the $\mathrm{Ca}-\mathrm{K}$ geopolymer matrix. These results are supported by IR analysis, which has demonstrated that the deconvoluted spectrum of the layer formed between the $\mathrm{Ca}-\mathrm{K}$ geopolymer matrix and the pellets contains bands belonging to both materials, the geopolymer matrix and the ash pellets.

\section{CONCLUSION}

The $\mathrm{Ca}-\mathrm{K}$ geopolymer matrix and solidified fluid fly ash shaped into pellets (aggregates) were used for a composite preparation. It was found that these two different waste-based materials could be combined to create together specific solid, insoluble matter.

The formation of an inseparable interlayer between the $\mathrm{Ca}-\mathrm{K}$ geopolymer matrix and the ash pellets has been corroborated by SEM and IR analyses. Not only are the pellets enveloped by the matrix, but their surface also reacts with the $\mathrm{Ca}-\mathrm{K}$ geopolymer binder.
SEM and EDS have proven the migration of calcium and potassium ions on the interface of the geopolymer matrix and the edges of the aggregates. They have also shown that the predominantly amorphous geopolymer matrix in contact with the aggregates contains wellencapsulated crystal forms of arcanite or also ettringite. A comparison of the spectra of the geopolymer matrix and the ash pellets with the spectrum of the layer formed between these materials has revealed that this interlayer contains vibrational bands that were detected in both original participants.

The water-insoluble pellets formed from the mixture of fluid fly ash and bentonite could be used as fillers or aggregates in different kinds of cementitious matter. The fabrication of larger and smaller pellets based on solidified fluid fly ash opens new ways to reuse the constantly increasing amounts of ash from coal-burning systems. Their possible combination with different waste-based materials can improve waste-material disposal.

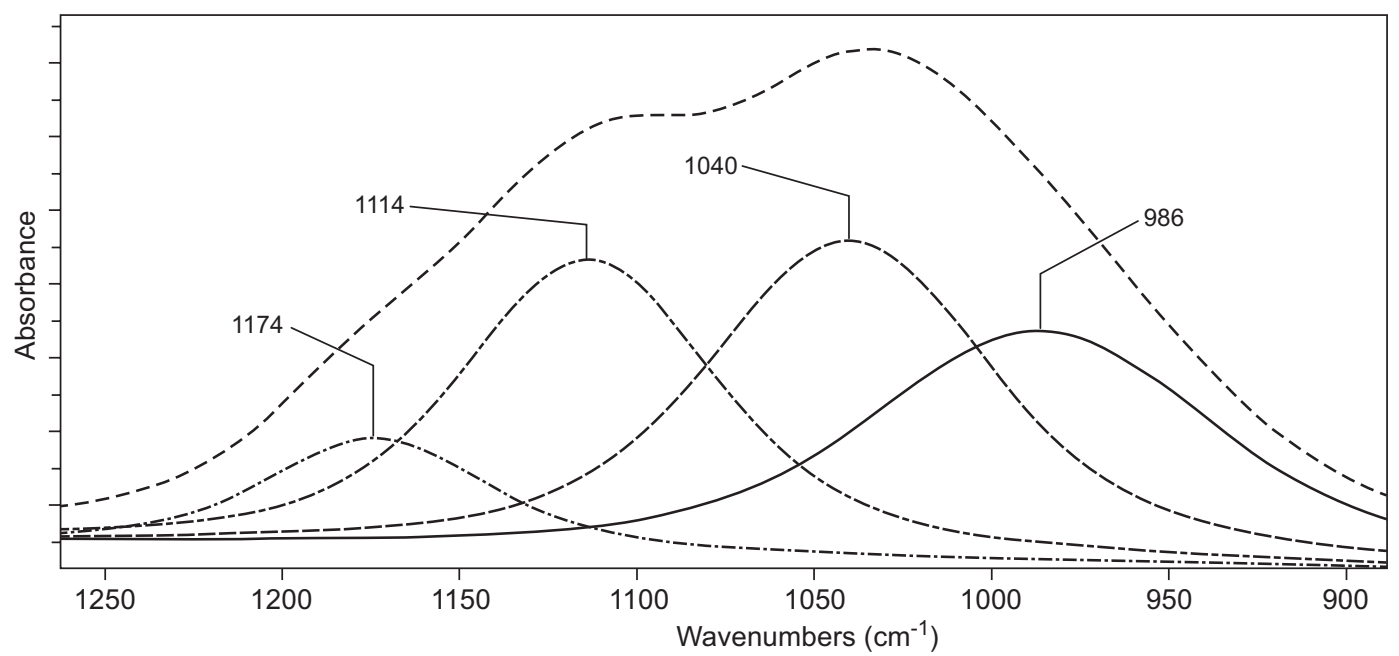

Figure 8. Deconvolution of the complex bands of the ash pellets prepared from fluid fly ash in a mixture with bentonite.

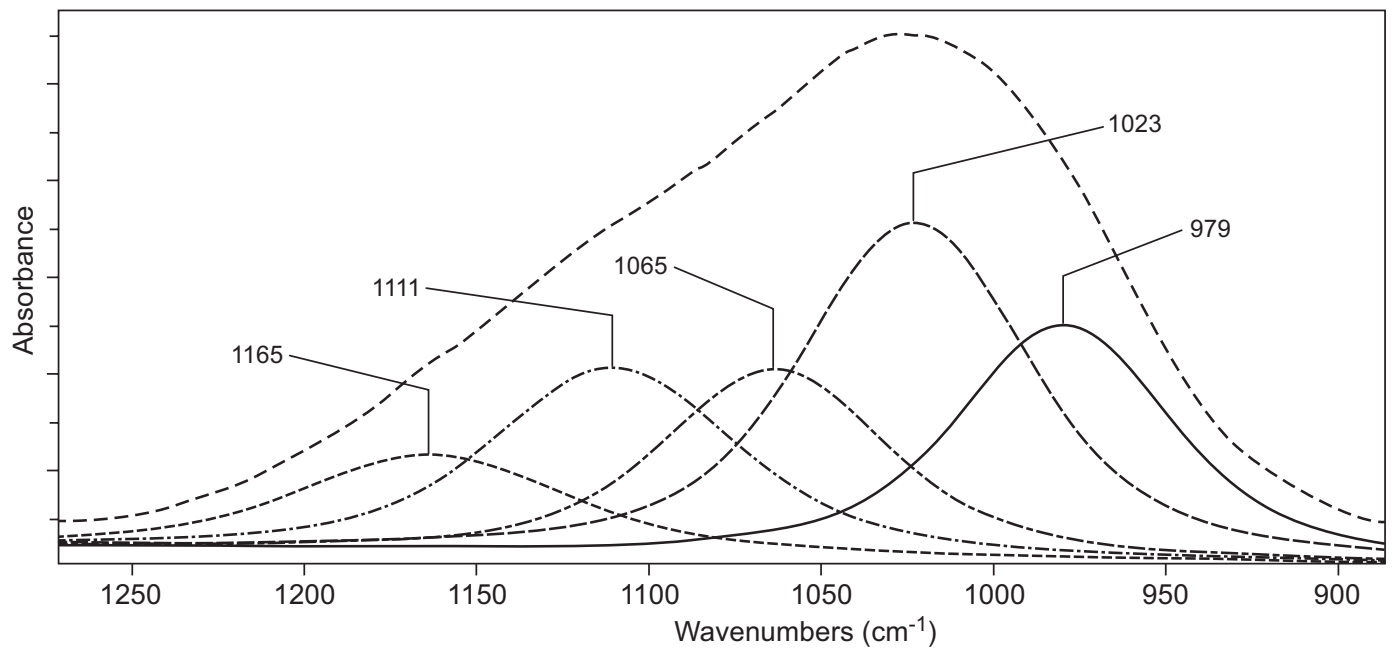

Figure 9. Deconvolution of the complex bands of the "interspace" between the pellets and the geopolymer matrix. 
Acknowledgments

This work has been carried out thanks to the support of the long-term conceptual development of the research organization RVO: 67985891. The authors thank Ms. M. Žaloudková from Institute of Rock Structure and Mechanics (Czech Republic) for measuring SEM analyses.

\section{REFERENCES}

1. Ahmaruzzaman M. (2010): A review on the utilization of fly ash. Progress in energy and combustion science, 36(3), 327-363. doi:10.1016/j.pecs.2009.11.003.

2. Blissett R. S., Rowson N. A. (2012): A review of the multi-component utilisation of coal fly ash. Fuel, 97, 1-23. doi:10.1016/j.fuel.2012.03.024.

3. Golden D. M. (1986): EPRI coal ash utilization research. Energy, 11(11), 1377-1387. doi:10.1016/0360-5442(86) 90074-5.

4. Mondragon F., Rincon F., Sierra L., Escobar J., Ramirez J., Fernandez J. (1990): New perspectives for coal ash utilization: synthesis of zeolitic materials. Fuel, 69(2), 263-266. doi:10.1016/0016-2361(90)90187-U.

5. Siddique R. (2010): Utilization of coal combustion by pro-ducts in sustainable construction materials. Resources, Con-servation and Recycling, 54(12), 1060-1066. doi:10.1016/j.resconrec.2010.06.011.

6. Iyer R. S., Scott J. A. (2001): Power station fly ash - a review of value-added utilization outside of the construction industry. Resources, Conservation and Recycling, 31(3), 217-228. doi:10.1016/S0921-3449(00)00084-7.

7. Guo Y., Li Y., Cheng F., Wang M., Wang X. (2013): Role of additives in improved thermal activation of coal fly ash for alumina extraction. Fuel processing technology, 110, 114-121. doi:10.1016/j.fuproc.2012.12.003.

8. Zhang J., Dong W., Li J., Qiao L., Zheng J., Sheng J. (2007): Utilization of coal fly ash in the glass-ceramic production. Journal of hazardous materials, 149(2), 523526. doi:10.1016/j.jhazmat.2007.07.044.

9. Sukmak P., Horpibulsuk S., Shen S. L. (2013): Strength development in clay-fly ash geopolymer. Construction and Building Materials, 40, 566-574. doi:10.1016/j. conbuildmat.2012.11.015.

10. Sukmak P., Horpibulsuk S., Shen S. L., Chindaprasirt P., Suksiripattanapong C. (2013): Factors influencing strength development in clay-fly ash geopolymer. Construction and Building Materials, 47, 1125-1136. doi: 10.1016/j. conbuildmat.2013.05.104.

11. Takada T., Hashimoto I., Tsutsumi K., Shibata Y., Yamamuro S., Kamada T., Inoue K., Tsuzura K., Yoshida K. (1995): Utilization of coal ash from fluidized-bed combustion boilers as road base material. Resources, Conservation and Recycling, 14(2), 69-77. doi:10.1016/ S0921-3449(95) 80001-8.

12.Hlincik T., Buryan P. (2013): Evaluation of limestones for the purposes of desulphurisation during the fluid combustion of brown coal. Fuel, 104, 208-215. doi:10.1016/j.fuel. 2012.09.074.

13. Murray H.H. (2007). Applied Clay Mineralogy. $1^{\text {st }}$ ed., Elsevier.

14. Thomas L. (2002). Coal geology. John Wiley \& Sons.

15. Spears D. A. (2000): Role of clay minerals in UK coal combustion. Applied Clay Science, 16(1), 87-95. doi:10.1016/S0169-1317(99)00048-4.

16.Perná I., Hanzlíček T., Straka P., Steinerová M. (2007): Solidification of fluidized-bed ashes. Acta Research Reports, 16, 7-14.

17.Hanzlíček T.,Perná I. (2011): The alumina-silicates in stabilization processes in fluidized-bed ashes. CeramicsSilikáty, 55(1), 94-99.

18.Perná I., Hanzlíček T. (2013): Využití odpadních materiálů pro př́ipravu brusných nástrojů na bázi anorganických polymerů (Utilization of waste materials for preparation of abrasive tools on base of inorganic polymers), Waste forum (www.wasteforum.cz), 1, 29-36.

19.Perná I., Hanzlíček T. (2016): The setting time of a clay-slag geopolymer matrix: the influence of blastfurnace-slag addition and the mixing method. Journal of Cleaner Production, 112, 1150-1155. doi:10.1016/j. jclepro.2015.05. 069.

20.Perná I., Hanzliček T., Boura P., Lučaník A. (2016): The Manufacture of the Grinding Wheels Based on the $\mathrm{Ca}-\mathrm{K}$ Geopolymer Matrix. Materials and Manufacturing Processes, 31(5), 667-672. doi:10.1080/10426914.2015.1 004709.

21.Rees C. A., Provis J. L., Lukey G. C., van Deventer J. S. (2007): Attenuated total reflectance fourier transform infrared analysis of fly ash geopolymer gel aging. Langmuir, 23(15), 8170-8179. doi:10.1021/la700713g.

22.Lee W. K. W., Van Deventer J. S. J. (2003): Use of infrared spectroscopy to study geopolymerization of heterogeneous amorphous aluminosilicates. Langmuir, 19(21), 8726-8734. doi:10.1021/la026127e.

23. Sitarz M., Mozgawa W., Handke M. (1997): Vibrational spectra of complex ring silicate anions - method of recognition. Journal of Molecular Structure, 404(1), 193-197. doi:10.1016/S0022-2860(96)09381-7.

24.Lecomte I., Henrist C., Liegeois M., Maseri F., Rulmont A., Cloots R. (2006): (Micro)-structural comparison between geopolymers, alkali-activated slag cement and Portland cement. Journal of the European Ceramic Society, 26(16), 3789-3797. doi:10.1016/j.jeurceramsoc.2005.12.021.

25.Madejová J. (2003): FTIR techniques in clay mineral studies. Vibrational spectroscopy, 31(1), 1-10. doi:10.1016/ S0924-2031(02)00065-6. 